\title{
Revitalisasi PLTS Off-Grid 15 kWp Desa Datah Sebagai Catu Daya Pompa Air Pedesaan
}

\author{
I.G.A.D. Sasmita ${ }^{1}$, I.A.D. Giriantari ${ }^{2}$, I.N.S. Kumara ${ }^{3}$ \\ Submission: 15-08-2019, Accepted: 02-09-2019
}

\begin{abstract}
A 15 kWp off-grid photovoltaic system in Asah Teben Village Karangasem was built by the Ministry of Energy and Mineral Resources in 2013, but is currently not utilized due to expansion of PLN electricity network. Meanwhile, residents of Asah Teben village experience water shortages. The villagers' water sources are far away and the terrain that is steeped from the settlements makes it difficult for residents to get water for their daily needs. In this study, a proposal to revitalize the offgrid PV system by using it as a power supply for two drinking water distribution pumps for residents of Asah Teben village is presented. The water pumping system consists of a submersible pump to lift water from a spring to a reservoir, a distribution pump to distribute water from the reservoir through pipes closer to the residentials area. The solar PV water pumping system has been designed with a total investment cost of IDR 330,850,000. The investment analysis shows the water selling price is IDR 1,288 per cubic meter which is lower than the current local utility water rate. This solar PV water supply system is managed by the village enterprises BUMDes Datah Swakarya Mukti Raharja.
\end{abstract}

Keywords-Renewable Energy, Off-grid PV, Water Pumps, Solar Pumping, Water Distribution

Intisari- PLTS off-grid $15 \mathrm{kWp}$ di Dusun Asah Teben Karangasem dibangun oleh Kementerian ESDM pada tahun 2013, namun saat ini tidak dimanfaatkan karena masuknya jaringan listrik PLN. Sementara itu, warga Dusun Asah Teben mengalami kekurangan air. Sumber air warga dusun berjarak jauh dan medan yang ditempuh terjal dari permukiman, sehingga warga kesulitan mendapatkan air untuk kebutuhan sehari-hari. Penelitian ini mencoba merevitalisasi PLTS tersebut dengan menggunakannya sebagai catu daya dua buah pompa distribusi air minum bagi warga Dusun Asah Teben. Sistem pompa air yang dirancang terdiri dari pompa submersibel untuk mengangkat air dari sumber mata air ke bak penampungan, pompa distribusi untuk mendistribusikan air dari bak penampungan melalui jaringan pipa ke warga. Sistem pompa air dengan PLTS sebagai catu daya telah dirancang dengan biaya investasi Rp. 330.850.000. Dari hasil kajian investasi, air dijual dengan harga air $\mathbf{1 . 2 8 8}$ per meter kubik yang lebih murah dari harga air PDAM. Sistem penyediaan air bertenaga matahari ini dikelola dikelola oleh BUMDes Datah Swakarya Mukti Raharja.

Kata Kunci- Energi Terbarukan, PLTS off-grid, Pompa, Distribusi Air

\footnotetext{
${ }^{1}$ Mahasiswa, Pascasarjana Magister Teknik Elektro Universitas Udayana, Jln. Bakung Sari Gang Kresek No.1 Kuta Badung, Kode Pos: 80361; (Hp: 081936665705; e-mail: nandayock@gmail.com )

2,3 Dosen Jurusan Teknik Elektro dan Komputer Fakultas Teknik Universitas Udayana, Jln. Jalan Kampus Bukit Jimbaran 80361 INDONESIA (telp: 0361-703315; fax: 0361-4321; e-mail:
}

I.G.A. Sasmita dkk: Revitalisasi PLTS Off-Grid 15 kWp

\section{Pendahuluan}

Pembangkit Listrik Tenaga Surya di Desa Datah telah memproduksi energi listrik sejak tahun 2013 dan merupakan milik Kementrian ESDM telah dihibahkan ke Pemerintah Daerah. Namun, sejak masuknya listrik dari PLN aset tersebut tidak dimanfaatkan dimanffatkan secara optimal oleh masyarakat karena ada beberapa bagian yang mengalami kerusakan [1]. Warga dusun lebih memilih menggunakan listrik dari PLN yang lebih stabil dan lebih mudah penggunaannya. Tidak terawatnya PLTS Datah menyebabkan salah satu dari tiga inverter yang ada mengalami kerusakan, sehingga daya yang dihasilkan PLTS tidak bisa maksimal dari kapasitas yang seharusnya $15 \mathrm{kWp}$ hanya menghasilkan daya $10 \mathrm{kWp}$. Berdasarkan obervasi lapangan didapatkan bahwa komponen yang lain seperti panel surya dan baterai masih berfungsi dengan baik. Karena hal tersebut, diperlukan adanya upaya revitalisasi aset PLTS tersebut.

Dusun Asah Teben Karangasem memiliki luas $6,74 \mathrm{~km}^{2}$ dan memiliki populasi yang cukup tinggi dengan jumlah penduduk sebanyak 315 kepala leluarga pada tahun 2018. Dengan kepadatan seperti itu menurut Sularso maka kebutuhan air tiap orang sekitar 150-liter per hari per orang [2]. Dengan nilai seperti itu, maka kebutuhan air di Dusun Asah Teben dalam kategori lumayan tinggi. Berdasarkan Peta hidrologi pulau Bali, kandungan air tanah di sekitar lokasi tersebut, yakni di sekitar wilayah Kecamatan Abang, di sekitar kaki Gunung Agung memiliki kandungan air sangat sedikit yaitu berkisar antara 0,1 liter per detik [3]. Dengan nilai debit tersebut dapat dikatakan belum memenuhi kebutuhan air masyarakat di dusun tersebut.

Daya listrik dari PLTS off-grid Datah yang tidak lagi dimanfaatkan untuk penerangan dan pengoperasian alat elektronik warga sekitar, dapat digunakan sebagai solusi permasalahan air di desa tersebut. Dengan merevitalisasi PLTS sehingga daya listrik yang dihasilkan dapat dimanfaatkan sebagai catu daya sistem pemompaan air warga dusun, karena sistem pompa air PLTS lebih efektif daripada pompa diesel baik dari segi perhitungan dan total biaya investasi [4]. Dengan kapasitas daya $10 \mathrm{kWp}$ diharapkan nantinya kebutuhan air bersih di pemukiman warga dapat terpenuhi. Pemanfaatan PLTS akan dimulai dengan studi dan perancangan untuk memanfaatkan PLTS tersebut secara maksimal dan efisien. Parameter seperti tekanan pompa, jarak, ketinggian, spesifikasi pompa, jalur air, dan lain sebagainya harus diperhitungkan agar kapasitas PLTS dapat dipakai secara maksimal dan air yang didistribusikan bisa memenuhi kebutuhan warga.

Berdasarkan latar belakang di atas, penelitian ini akan membahas mengenai revitalisasi PLTS off-grid $15 \mathrm{kWp}$ Dusun Datah Karangasem sebagai catu daya pompa air p-ISSN:1693 - 2951; e-ISSN: 2503-2372 
pedesaan untuk mengangkat dan mendistribusikan air dari sumber mata air ke wilayah pemukiman desa.

\section{PLTS OFF-GRID 15 KWP DESA DATAH}

Salah satu sumber energi terbarukan yang tidak ada habisnya adalah sinar matahari, yang dapat dimanfaatkan sebagai sumber Pembangkit Listrik Tenaga Surya (PLTS) [5]. PLTS adalah pembangkit yang mengkonversikan energi foton dari surya menjadi energi listrik. Konversi ini terjadi pada panel surya yang terdiri dari sel-sel photovoltaik. Sel-sel ini terdiri dari lapisan-lapisan tipis dari silikon ( $\mathrm{Si}$ ) murni dan bahan semi konduktor lainnnya [6]. Sistem teknologi PLTS Fotovoltaik salah satu sumber energi listrik alternatif yang siap digunakan saat ini secara masal [7] [8]. PLTS memanfaatkan energi surya langsung untuk menghasilkan listrik DC (Direct Current), yang kemudian dapat diubah menjadi listrik AC (Alternating Current) apabila diperlukan, dengan inverter. PLTS merupakan pembangkit daya listrik yang dapat dirancang untuk memenuhi kebutuhan listrik dari yang kecil sampai dengan yang besar.

Di Bali berpotensi untuk dikembangkan pembangkit listrik tenaga surya [9]. Salah satu PLTS yang ada di Bali adalah PLTS Datah yang terletak di Dusun Asah Teben, Desa Datah, Kecamatan Abang, Kabupaten Karangasem. PLTS Datah merupakan PLTS off-grid yang menghasilkan daya sebesar $15 \mathrm{kWp}$. Karena kurangnya perawatan menyebabkan salah satu dari tiga inverter mengalami kerusakan, sehingga listrik yang dihasilkan hanya $10 \mathrm{kWp}$. Diharapkan daya yang dihasilkan dapat membantu kebutuhan listrik untuk warga dan penerangan jalan sekitar desa.

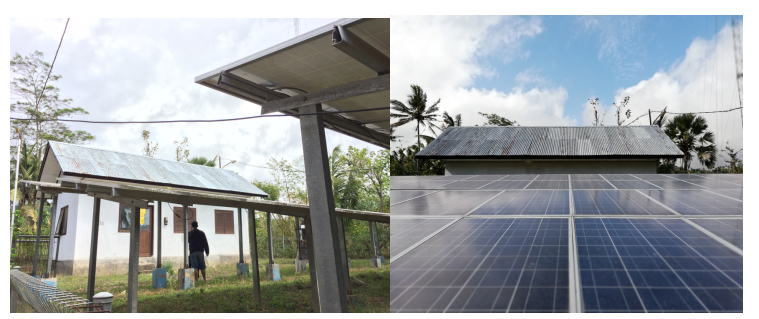

Gambar 1. PLTS off-grid $15 \mathrm{kWp}$ Datah

PLTS Datah dibangun pada tahun anggaran 2013 oleh Kementerian ESDM. PLTS Datah telah dihibahkan ke Pemerintah Kabupaten Karangasem, dan kemudian sudah diserahkan kepada pengelolanya di masyarakat. Tetapi, setelah masuknya jaringan listrik PLN ke Dusun Asah Teben, PLTS tidak dimanfaatkan secara maskimal.

Masyarakat Dusun Asah Teben sebenarnya mengalami kekurangan air bersih. Sumber-sumber air yang ada antara lain PAM Desa, cubang air hujan, sungai, dan mata air. Untuk mengambil air ke mata air dibutuhkan waktu yang cukup lama karena medan yang terjal menuruni tebing. Salah satu solusi adalah membangun sistem pompa air yang dicatu dengan PLTS off-grid yang sudag ada di desa. Sehingga, PLTS Datah yang terbengkalai dapat difungsikan kembali untuk memenuhi kebutuhan air warga di Dusun Asah Teben.

\section{METODE PENELITIAN}

ISSN $1693-2951$
Tahapan penelitian ini disajikan pada diagram alur seperti diperlihatkan pada Gambar 2.

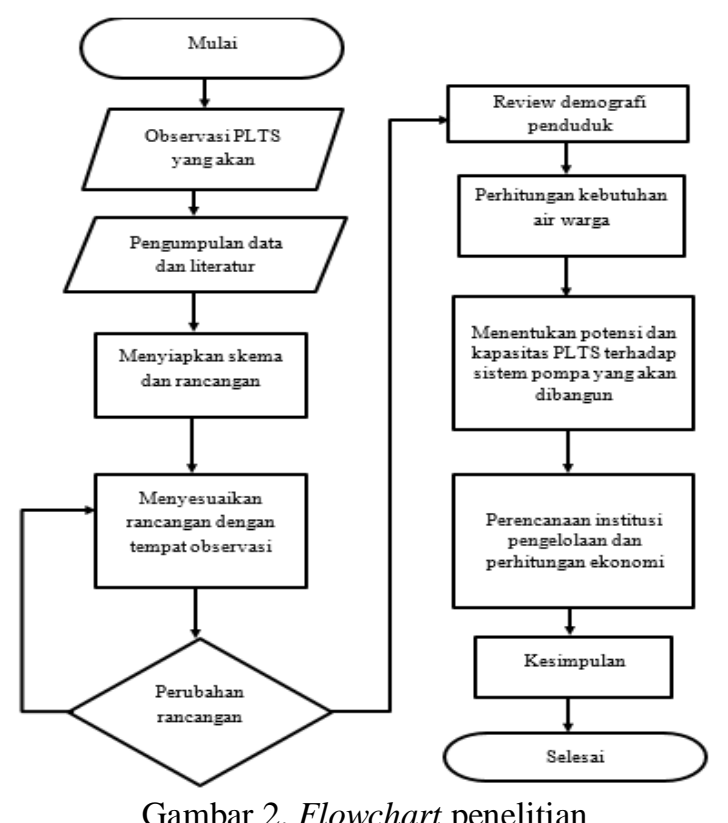

Langkah pertama adalah melakukan observasi terhadap PLTS Datah. Setelah itu melakukan studi literatur terkait sistem pompa bertenag amatahari. Menmbuat skema dan rancangan sistem pemompaan air. Menghitung demografi penduduk Dusun Asah Teben. Menghitung perkiraan kebutuhan air bersih masyarakat berdasarkan proyeksi dari jumlah penduduk dan fasilitas-fasilitas di Dusun Asah Teben. Penentuan tipe pompa yang akan digunakan untuk penyediaan air bersih. Analisis sistem pompa air yang telah ditentukan berdasarkan tipe pompa guna untuk pemenuhan kebutuhan air bersih dan perhitungan kapasitas yang sesuai dengan kapasitas PLTS Datah. Perancangan pengelolaan dan perawatan sistem distribusi air bersih kedepannya.

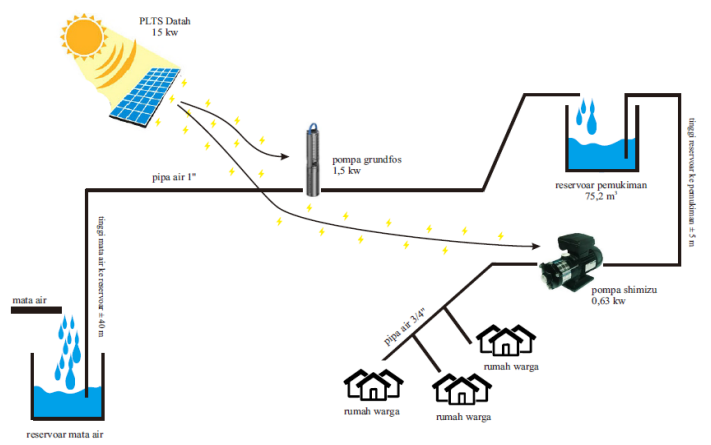

Gambar 3. Rancangan sistem pompa air bertenaga matahari

Perkiraan Pertumbuhan Penduduk dapat dihitung melaui persamaan berikut [10]:

$$
\mathrm{Pt}=\mathrm{Po} \mathrm{e}^{\mathrm{rt}} \text { ataul } \mathrm{r}=\frac{1}{\mathrm{t}} \ln \left(\frac{\mathrm{pt}}{\mathrm{po}}\right)
$$

I.G.A. Sasmita dkk: Revitalisasi PLTS Off-Grid 15 kWp 
Dimana:

$$
\begin{aligned}
& \mathrm{Pt}=\text { Jumlah penduduk tahun ke } \mathrm{t}(\mathrm{jiwa}) \\
& \mathrm{Po}=\text { Jumlah penduduk awal perencanaan (jiwa) } \\
& \mathrm{t}=\text { Jangka waktu (tahun) } \\
& \mathrm{r}=\text { Laju pertumbuhan penduduk } \\
& \mathrm{e}=\text { Bilangan exponensial }(2,718)
\end{aligned}
$$

Kebutuhan Air Penduduk dapat dihutung dengan persamaan berikut [11]:

$$
\mathrm{Q}=\mathrm{p} \times \mathrm{q}
$$

Dengan pengertian:

$\mathrm{Q}=$ Kebutuhan air (Liter/hari)

$\mathrm{q}=$ Kebutuhan air perorang perhari (Liter/orang/hari)

$\mathrm{P}=$ Jumlah jiwa yang dilayani sesuai dengan tahun perencanaan (jiwa)

Secara umum ada tiga sumber untuk penyediaan air bersih yaitu mata air, air tanah dan air permukaan (sungai, danau, lainnya) [12]. Dalam jurnal ini menggunakan mata air, yang akan dihitung debitnya untuk memperkirakan perancangan sistem pompa.

Debit merupakan volume air yang mengalir per satuan waktu [13]. Menghitung debit air menggunakan cara tradisional dengan metode pengisian air dalam ember atau botol, dengan menghitung lama waktu untuk air memenuhi volume ember/botol tersebut. Debit dihitung dengan menggunakan persamaan [13]:

$$
\text { Debit air }=\frac{\text { wolume }}{\text { wahtu }}
$$

Menghitung kapasitas reservoir yang diperlukan dapat menggunakan persamaan sebagai berikut [2]:

$$
\frac{\text { volume regawpir }}{\text { wolume ke butuhanperhari }}=25 \text { sampai } 30 \%
$$

Pompa merupakan peralatan mekanis atau mesin yang digunakan untuk mendistribusikan cairan dari dataran rendah ke dataran tinggi. Prinsip kerja pompa dengan cara penekanan dan penghisapan cairan [14]. Jenis pompa antara lain pompa air, pompa diesel, pompa hydram, pompa bahan bakar yang digunakan oleh masyarakat pada umumnya. Dari banyaknya jenis pompa yang ada tentu mempunyai kerja dan kegunaan yang berbeda namun memiliki fungsi yang sama [15].

Untuk menghitung performa PLTS jika digunakan sebagai catu daya pompa yang pertama dilakukan adalah menghitung arus yang dibutuhkan oleh total kebutuhan daya pompa [16], dapat diketahui dengan persamaan:

$$
\text { Arus }=\left(\frac{\text { Watt }}{\text { beban }}\right) / \text { voltase baterai PLTS }
$$

Untuk mengetahui harga air dapat dihitung dengan persamaan berikut [11]:

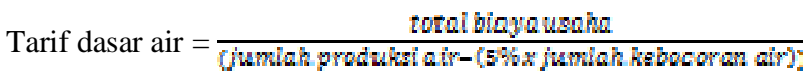

\section{HASIL DAN PEMBAHASAN}

\section{A. Penduduk Dusun asah Teben}

Penduduk di Dusun Asah Teben bermata pencaharian sebagai petani dimana tanaman pangan yang dibudiayakan meliputi jagung dan ubi kayu. Di samping itu, terdapat usaha kerajinan yaitu kerajinan gula aren, minuman tradisional arak bali, dan kerajinan-kerajinan lainnya. Penduduk Dusun Asah Teben menurut Kantor Desa Datah mengalami pengurangan akibat beberapa faktor seperti kematian, kawin keluar, dan pindah ke desa lain. Berikut data penduduk Dusun Asah Teben.

Tabel 1. Penduduk Asah Teben

\begin{tabular}{cc}
\hline Tahun & Jumal Penduduk (jiwa) \\
\hline 2017 & 1336 \\
\hline 2018 & 1331 \\
\hline
\end{tabular}

\section{B. Perkiraan Pertumbuhan Penduduk}

Perkiraan jumlah penduduk diperlukan untuk memprediksi perkembangan penduduk di masa depan. Dengan umur perencanaan sekitar lima tahun ke depan maka berdasarkan persamaan (1) yang telah dijabarkan sebelumnya diperoleh hasil sebagai berikut:

Tabel 2. Perkiraan penduduk Dusun Asah Teben

\begin{tabular}{lllllll}
\hline \multirow{2}{*}{ Bulan } & \multicolumn{6}{c}{ Jumlah Penduduk (jiwa) } \\
\cline { 2 - 7 } & $\mathbf{2 0 1 9}$ & $\mathbf{2 0 2 0}$ & $\mathbf{2 0 2 1}$ & $\mathbf{2 0 2 2}$ & $\mathbf{2 0 2 3}$ & $\mathbf{2 0 2 4}$ \\
\hline Januari & 1325 & 1324 & 1319 & 1315 & 1310 & 1306 \\
\hline Februari & 1327 & 1325 & 1320 & 1316 & 1311 & 1307 \\
\hline Maret & 1327 & 1325 & 1320 & 1316 & 1311 & 1307 \\
\hline April & 1329 & 1325 & 1320 & 1316 & 1311 & 1307 \\
\hline Mei & 1329 & 1325 & 1320 & 1316 & 1311 & 1307 \\
\hline Juni & 1328 & 1324 & 1319 & 1315 & 1310 & 1306 \\
\hline Juli & 1325 & 1321 & 1316 & 1312 & 1307 & 1303 \\
\hline Agustus & 1325 & 1321 & 1316 & 1312 & 1307 & 1303 \\
\hline September & 1326 & 1322 & 1317 & 1313 & 1308 & 1304 \\
\hline Oktober & 1326 & 1322 & 1317 & 1313 & 1308 & 1304 \\
\hline November & 1322 & 1318 & 1313 & 1309 & 1304 & 1300 \\
\hline Desember & 1320 & 1316 & 1311 & 1307 & 1302 & 1298 \\
\hline
\end{tabular}


Dari Tabel 2 dapat dilihat penurunan jumlah penduduk. Dari jumlah penduduk ini, dapat diketahui berapa kebutuhan air bersih bagi penduduk di Dusun Asah Teben.

\section{Kebutuhan Air}

Dari data pada Tabel 2, dengan asumsi bahwa kebutuhan air per orang per hari sebesar 150 liter [2], maka didapatkan data kebutuhan air penduduk berdasarkan persamaan (2) yang telah dijabarkan sebelumnya diperoleh hasil sebagai berikut:

Tabel 3. Perkiraan kebutuhan air bersih Dusun Asah Teben

\begin{tabular}{lllllll}
\hline \multirow{2}{*}{ Bulan } & \multicolumn{6}{c}{ Kebutuhan Air Tahunan $\left(\mathbf{m}^{\mathbf{3}}\right)$} \\
\cline { 2 - 7 } & $\mathbf{2 0 1 9}$ & $\mathbf{2 0 2 0}$ & $\mathbf{2 0 2 1}$ & $\mathbf{2 0 2 2}$ & $\mathbf{2 0 2 3}$ & $\mathbf{2 0 2 4}$ \\
\hline Januari & 5963 & 5907 & 5851 & 5796 & 5742 & 5688 \\
\hline Februari & 5972 & 5915 & 5860 & 5805 & 5751 & 5697 \\
\hline Maret & 5972 & 5915 & 5860 & 5805 & 5751 & 5697 \\
\hline April & 5947 & 5891 & 5836 & 5781 & 5727 & 5673 \\
\hline Mei & 5947 & 5891 & 5836 & 5781 & 5727 & 5673 \\
\hline Juni & 5942 & 5886 & 5831 & 5777 & 5722 & 5669 \\
\hline Juli & 5929 & 5873 & 5818 & 5764 & 5709 & 5656 \\
\hline Agustus & 5929 & 5873 & 5818 & 5764 & 5709 & 5656 \\
\hline September & 5933 & 5878 & 5822 & 5768 & 5714 & 5660 \\
\hline Oktober & 5933 & 5878 & 5822 & 5768 & 5714 & 5660 \\
\hline November & 5915 & 5860 & 5805 & 5751 & 5697 & 5643 \\
\hline Desember & 5907 & 5851 & 5796 & 5742 & 5688 & 5635 \\
\hline
\end{tabular}

Data kebutuhan air mengikuti jumlah pertumbuhan penduduk. Yang mana pada data penduduk terjadi penurunan maka data perkiraan kebutuhan air penduduk juga mengikuti penurunan. Dari data pada Tabel 3 didapat hasil perhitungan jumlah kebutuhan air warga setiap bulan.

\section{Debit Air}

Dalam perngukuran debet air pada mata air, menggunakan ember dengan kapasitas 5-liter kemudian dihitung menggunakan stopwatch waktu yang diperlukan untuk air mengisi penuh ember tersebut.

Dari hasil pengukuran debit mata air pada tanggal 7 September 2018 diperoleh melalui persamaan (3) perhitungan dengan pengisian ember 5-liter dan menghitung lama waktu untuk penuh yaitu dalam waktu 4,07 detik yang berarti debit air yang mengalir yaitu 5 liter $/ 4,07$ detik $=1,22$ liter $/$ detik $=$ 354.098 liter/hari $=4.392$ liter/jam.

\section{E. Kapasitas Reservoir}

Untuk menjalankan sistem pompa air, maka diperlukan penampungan atau yang biasa disebut reservoir. Diketahui rata-rata kebutuhan air warga perhari sebesar 250,6 $\mathrm{m}^{3}$. Maka kapasitas reservoir yang akan dibuat dapat dihitung melauli persamaan (4) sebagai berikut:

\section{$\frac{\text { volume reservoir }}{\text { volume kebutuhan perh ari }}=25$ sampai $30 \%$}

Dari persamaan (4) maka diperoleh perhitungan kapasitas reservoir yang akan dibangun sebagai berikut:

$$
\frac{\text { volume reservoin }}{250687 \text { liter }}=0,3
$$

$\mathrm{V}=250,6 \mathrm{~m}^{3} \times 0,3=75,206$ liter

Volume reservoir $=75,206$ liter

Dengan kapasitas reservoir $75,2 \mathrm{~m}^{3}$ maka:

Tinggi reservoir $=2$ meter

Lebar reservoir $=7,6$ meter

Panjang reservoir $=5$ meter

Jadi kapasitas reservoir yang akan dibangun $75,2 \mathrm{~m}^{3}$

Kapasitas reservoir tersebut apabila dicocokkan dengan data kebutuhan air bersih warga yang dipeoleh dari wawancara dengan lima orang responden, maka kapasitas reservoir sangat melebihi untuk memenuhi kebutuhan air warga dikarenakan pembuatan reservoir telah dihitung dengan kebutuhan air warga sebesar 150 liter perhari. Sedangkan di Dusun Asah Teben Desa Datah kebutuhan air warga rata-rata perhari berkisar 45,64 liter perharinya. Jika dibandingkan hanya sepertiga dari hasil perhitungan.

\section{F. Kapasitas Pompa Air}

Dengan ketinggian antara sumber mata air dan pemukiman yang akan dialiri air untuk reservoir yaitu setinggi 40 meter dan dengan debit air sejumlah 4392 m3/jam maka pompa yang cocok digunakan yaitu dengan pompa submersible yaitu jenis pompa air yang dirancang khusus karena diletakkan didalam air dan mendorong air melalui pipa salurannya untuk menuju ke permukaan. Salah satu tipe pompa submersible yang cocok digunakan yaitu pompa Grundfos dengan tipe SP 5A-17 dengan spesifikasi sebagai berikut :

Table 4. Spesifikasi pompa Grundfos SP 5A-17

\begin{tabular}{lr}
\hline \multicolumn{1}{c}{ Parameter } & Nilai \\
\hline Daya (Watt) & 1500 \\
\hline Frekuensi (Hz) & 50 \\
\hline Tegangan (Volt) & $380 / 400 / 415$ \\
\hline Phase & 3 \\
\hline Rated speed $(\mathrm{rpm})$ & 2870 \\
\hline Rated flow $\left(\mathrm{m}^{3} / \mathrm{h}\right)$ & 5 \\
\hline Rated height $($ meter $)$ & 70 \\
\hline
\end{tabular}

Jumlah total pompa yang akan digunakan sebanyak 2 buah. Satu digunakan untuk memompa air ke reservoir dan satunya lagi untuk pendistribusian air ke permukiman penduduk. Dari Tabel 4 maka diperoleh daya pompa submersible sebesar $1,5 \mathrm{~kW}$ ( 3 phase). Jika dihitung per phase berarti daya dibagi tiga menjadi 500 watt (1 phase).

Untuk mendistribusikan air ke penduduk maka diperlukan pompa distribusi air dengan spesifikasi Tabel 5.

I.G.A. Sasmita dkk: Revitalisasi PLTS Off-Grid 15 kWp 
Tabel 5. Spesifikasi pompa Simizhu BWJT 2-4

\begin{tabular}{lr}
\hline \multicolumn{1}{c}{ Parameter } & \multicolumn{1}{c}{ Nilai } \\
\hline Daya & $638 \mathrm{~W}$ \\
\hline Frekuensi & $50 \mathrm{~Hz}$ \\
\hline Voltase & $220 \mathrm{volt}$ \\
\hline Phase & $1 \mathrm{phase}$ \\
\hline Rated flow & $2,5 \mathrm{~m}^{3} / \mathrm{h}$ \\
\hline Rated height & $29 \mathrm{~meter}$ \\
\hline
\end{tabular}

Dari Tabel 5 maka daya listrik pompa distribusi Simizhu sebesar 0,63 kW (1 phase)

Maka total kebutuhan listrik pompa air keseluruhan = daya pompa submersible + daya pompa distribusi $=0,5+0,63=1,13 \mathrm{~kW}$

$$
\begin{aligned}
\text { Arus }=\left(\frac{\text { Watt }}{\text { beban }}\right) / \text { voltage bateral PLTS } \\
=1,13 \mathrm{Kw} / 72 \\
=1130 / 72 \\
=15,69 \mathrm{~A}
\end{aligned}
$$

Waktu pemakaian $=$ kapassitas baterai $(\mathrm{Ah}) /$ arus

$$
\begin{aligned}
& =1000 \mathrm{Ah} / 15,69 \mathrm{~A} \\
& =63,73 \mathrm{jam}
\end{aligned}
$$

Waktu real $=$ waktu pemakaian - diefiensi baterai $(20 \%)$

$$
=63,73-12,75=50,98 \text { jam }
$$

Maka kapasitas baterai PLTS yang digunakan sebesar 1000Ah masih dapat memberikan energi untuk mengoperasikan seluruh pompa selama 50,98 jam. Dengan kondisi tersebut maka pompa dapat beroperasi setiap hari tanpa kekurangan energi dan meskipun dalam keadaan malam hari sekalipun maupun keadaan saat sinar matahari tertutup awan.

Untuk mengetahui pemakaian listrik PLTS sebagai catu daya pompa dapat dihitung melaui persamaan rumus berikut:

Kapasitas pompa 5000 liter per jam $=5 \mathrm{~m}^{3}$ Kapasitas reservoar 75.206 liter $=75,2 \mathrm{~m}^{3}$ Waktu penuh reservoar $\frac{75206}{5000}=15,04=15$ jam

$$
\begin{aligned}
& =\text { Total daya pompa } \mathrm{x} \text { jam pemakaian } \\
& =1.13 \mathrm{kw} \times 15 \mathrm{jam} \\
& =16,95 \mathrm{kWh} \text { perhari }
\end{aligned}
$$

Harga listrik golongan industri dengan daya PLTS 15 $\mathrm{kW}=\mathrm{Rp} .1 .467 \mathrm{kWh}$

Sedangkan untuk mengetahui nilai ekonomi dari daya yang digunakan pompa air dari PLTS dengan harga listrik dari PLN saat ini sebesar Rp. 1.1467 perkWh dapat dihitung melaui persamaan rumus berikut:

$$
\begin{aligned}
& =\mathrm{kWh} \text { pompa } \mathrm{x} \text { harga listrik PLN per } \mathrm{kWh} \\
& =16,95 \times 1,467 \\
& =24.865
\end{aligned}
$$

I.G.A. Sasmita dkk: Revitalisasi PLTS Off-Grid 15 kWp
Jadi biaya pemakaian listrik pompa air perhari dengan asumsi mesin pompa hidup 15 jam adalah sebesar Rp. 24.865 .

\section{G. Perhitungan Ekonomi Tarif Air Bersih}

Perhitungan ekonomi perlu dilakukan untuk mengetahui berapa biaya investasi yang diperlukan dan berapa laba yang diperoleh dari investasi yang telah dilakukan. Berikut biaya investasi solar pumping di Dusun Asah Teben Desa Datah. Perhitungan ekonomi dimulai dari biaya investasi antara lain:

Tabel 6. Komponen Investasi

\begin{tabular}{clr}
\hline No & Komponen & Harga (Rp) \\
\hline 1 & Pompa submersible grundfos & $15,650,000$ \\
\hline 2 & Pompa air shimizu bwjt 2-4 & $2,550,000$ \\
\hline 3 & Pipa HDPE 1 inch 250 meter & $6,250,000$ \\
\hline 4 & Reservoar dan tempat pompa & $25,000,000$ \\
\hline 5 & $5 x 10$ nyaf kabel 300 meter & $60,000,000$ \\
\hline 6 & Panel kelistrikan & $6,000,000$ \\
\hline 7 & Ruang panel listrik dan pompa air & $20,000,000$ \\
\hline 8 & Meteran air 412 buah & $185,400,000$ \\
\hline 9 & Pipa warga 3/4 inch 500 meter & $10,000,000$ \\
\hline & TOTAL & $330,850,000$ \\
\hline
\end{tabular}

Dari perhitungan biaya invertasi yang terdiri dari bahan dan jasa seperti pada Tabel 6 diperoleh hasil Rp. 330.850.000.

Tabel 7. Komponen operasional sistem air bersih

\begin{tabular}{lr}
\hline Komponen & Jumlah (Rp) \\
\hline Biaya pegawai 1 orang & $2,000,000$ \\
\hline Biaya pemeliharaan & $2,000,000$ \\
\hline Biaya penyusutan investasi 5 tahun & $5,514,167$ \\
\hline Laba 15\% & $1,427,125$ \\
\hline Biaya total 1 bulan & $10,941,292$ \\
\hline Biaya total 1 tahun & Rp. 131,295,500 \\
\hline
\end{tabular}

Biaya penyusutan diperoleh dari biaya invertasi dibagi 60 bulan ( 5 tahun).

Dari biaya operasional tersebut maka bisa dicari harga air yang diperoleh dari total biaya operasional 1 bulan kemudian dibagi perkiraan kebutuhan air, maka diperoleh nilai sebagai berikut:

Tabel 8. Perhitungan Tarif Dasar Air

\begin{tabular}{lr}
\hline \multicolumn{1}{c}{ Deskripsi } & \multicolumn{1}{c}{ Nilai } \\
\hline Total biaya usaha (Rp) & $462,145,500$ \\
\hline Jumlah produksi air(liter) & 354,098 \\
\hline Jumlah kebocoran diperkirakan 5\% (liter) & 17,705 \\
\hline Tarif dasar air perkubik (Rp) & $1,308.41$ \\
\hline
\end{tabular}

Untuk menentukan harga tarif dasar air, dapat dihitung melalui persamaan berikut:

Tarif dasar air $=$ Total biaya usaha dibagi (Jumlah Produksi air

$$
\begin{aligned}
& -(5 \% \text { x Jumlah kebocoran air })) \\
& =455.245 .500(354.098-(5 \% \text { x 17.705)) } \\
& =1.288 .87
\end{aligned}
$$$$
\text { p-ISSN:1693 - 2951; e-ISSN: 2503-2372 }
$$ 
Dari hasil perhitungan, tarif dasar air di Dusun Asah Teben adalah Rp. $1.288 / \mathrm{m}^{3}$. Sedangkan apabila dibandingkan dengan harga air PDAM bulan Juni 2019 di kabupaten Karangasem data dari PDAM Karangasem yang sebesar Rp. $1500 / \mathrm{m}^{3}$. Maka terhitung lebih murah dan terjangkau untuk warga sekitar. Dengan harga air yang murah diharapkan warga tepat waktu dalam membayar air yang telah digunakan. Sehingga kesinambungan sistem pompa air dapat terus memenuhi kebutuhan air penduduk di Dusun asah Teben Desa Datah.

\section{H. Struktur Organisasi Pengelolaan Air}

Dalam penelitian ini pengelolaan sistem air bersih di Dusun Asah Teben dikelola oleh BUMDes (Badan Usaha Milik Desa). Karena selama ini BUMDes yang telah mengelola sistem air bersih yang sudah ada di Desa Datah yaitu PAM Desa. Struktur organisasi BUMDes Datah Swakarya Mukti Raharja dapat dilihat pada gambar 4.

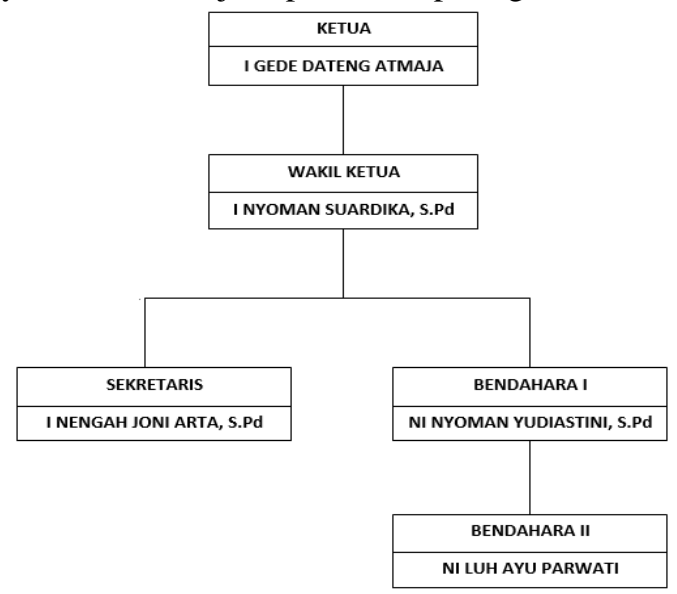

Gambar 4. Struktur Organisasi

\section{KESIMPULAN}

Dari hasil penelitian ini dapat diambil kesimpulan, sebagai berikut: Sistem pemompaan air di Dusun Asah Teben adalah terdiri dari pompa pengangkat air, pompa distribusi air, reservoir, dan jaringan distribusi pipa. Sistem pemompaan air ini dicatu dengan PLTS off-grid $15 \mathrm{kWp}$ Dusun Datah yang tidak termanfaatkan akibat masuknya jaringan PLN. Sistem pompa ini dapat memenuhi kebutuhan air wargasetempat. Untuk menjaga kesinambungan operasional sistem pemompaan air ini, pengelolaanya diserahkan kepada BUMDes Datah Swakarya Mukti Raharja yang ada di desa tersebut. Air yang didistribusikan ke warga dijual dengan Rp. $1.288 / \mathrm{m}^{3}$. Harga ini lebih rendah dari harga air PDAM sebesar Rp. $1.500 / \mathrm{m}^{3}$. Dengan harga ini BUMDes sudah mendapatkan laba sebesar $15 \%$.

\section{REFERENSI}

[1] Nusa. 2018. "Proyek PLTS Mangkrak". Nusa Bali, 29 Juli 2016. https://www.nusabali.com/berita/6477/proyek-plts-mangkrak.

[2] Sularso.(2004).Pompa dan Kompresor, Jakarta :Pradnya Paramita.

[3] Pemkab. 2011. http://karangasemkab.go.id/

[4] O.I. Sanjaya, I.A.D Giriantari, I.N. Satya Kumara. "Perancangan Sistem Pompa Irigasi Pembangkit Listrik Tenaga Surya (PLTS) Untuk Pertanian Subak Semaagung" E-Journal Spektrum, In Press.
[5] I.B.K. Sugirianta, I.A.D. Giriantari, I.N.S. Kumara. 2016. ”Analisa Keekonomian Tarif Listrik Pembangkit Listrik Tenaga Surya 1 MWP Bangli Dengan Metode Life Cycle Cost" Majalah Ilmiah Teknologi Elektro, Vol. 15, No.2, Juli-Desember 2016.

[6] Kadir,A. 2010. Energi: Sumber Daya, Inovasi, Tenaga Listrik dan Potensi Ekonomi, edisi 3. Jakarta: Universitas Indonesia.

[7] E.T.A.Duka, I.N. Setiawan, A.I. Weking. 2018."Perencanaan Pembangkit Listrik Tenaga Surya Hybrid Pada Area Parkir Gedung Dinas Cipta Karya Dinas Bina Marga dan Pengairan Kabupaten Badung" E-Journal Spektrum Vol. 5, No. 2 Desember 2018.

[8] N. S. Kumara. 2010. "Pembangkit Listrik Tenaga Surya Skala Rumah TanggaUrban Dan Ketersediannya Di Indonesia", Majalah Ilmiah Teknologi Elektro, Vol. 9, No.1, hal. 68-75, 2010

[9] P.A.R. Arimbawa, I.N.S. Kumara, R.S. Hartati. 2016."Studi Pemanfaatan Catu Daya Hibrida PLTS 3,7 KWP dan PLN Pada Instalasi Pengelolaan Air Limbah Desa Pemecutan Kaja Denpasar Bali” Majalah Ilmiah Teknologi Elektro, Vol. 15, No.2, Juli-Desember 2016.

[10] Titra. 2019. "Proyeksi Laju pertumbuhan Penduduk Di Indonesia Tahun 2019"[Tugas Akhir]. Medan : Universitas Sumatera Utara.

[11] Yanti Nurhotijah, Monang Situmorang, Asep Alipudin. 2017. "Analisi Perhitungan Harga Pokok Produksi Air Sebagai Dasar Penetapan Harga Jual Pada PDAM Tirta Jaya Mandiri Kabupaten Sukabumi Periode 2015-2016"Julnal Online Mahasiswa (JOM) Bidang Akuntansi Vol 2 No.2.

[12] Deny T. 2016 "Perencanaan Instalasi Pengolahan Air Minum Di Kecamatan Jatinangor Dan Kecamatan Cimanggung Kabupaten Sumedang" [Skripsi]. Bandung (ID): Fakultas Teknik Universitas Pasundan.

[13] A.K. Neno, H. Harijanto, A. Wahid. 2016."Hubungan Debit Air Dan Tinggi Muka Air Di Sungai Lambagu Kecamatan Tawaeli Kota Palu" Jurnal Warta Rimba, Vol. 4 No.2 Hal: 1-8 Desember 2016.

[14] Z.Iqtimal, I.D. Sara, Syahrizal. 2018."Aplikasi Sistem Tenaga Surya Sebagai Sumber Tenaga Listrik Pompa Air" Jurnal Online Teknik Elektro, Vol. 3 No.1 2018: 1-8.

[15] K.L. Yana, K.R. Dantes, N.A. Wigraha. 2017. "Rancang Bangun Mesin Pompa Air Dengan Sistem Recharging" Jurnal Jurusan Pendidikan Teknik Mesin (JJPTM) Vol: 8 No: 22017.

[16] Boxwell, M. 2009. "Solar Electricity Handbook". UK : Code Green Publishing. 